\title{
ANALISIS MODAL SOSIAL DALAM PEMBERDAYAAN EKONOMI KELUARGA MISKIN DI KELURAHAN KEDUNG JAYA, KECAMATAN TANAH SAREAL, KOTA BOGOR
}

(Analysis of Social Capital in Economic Empowerment of Poor Family at Kedung Jaya Village, Tanah Sareal Sub District, Bogor City)

\begin{abstract}
Alfiasari $^{1}$
The importance of social capital in poor family empowerment to increase their level of life is realized by most stakeholders. Some researchers stated that social capital has significant role in increasing family welfare. The aim of this research was to analyze the correlation between social capital and poor family empowerment through "UEK-SP KUBE Gakin" Program was conducted at Kedung Jaya village, Tanah Sareal sub district of Bogor, West Java. This research used cross sectional study as a study design. Sampling frame of this research were poor families which were intervened by "UEK-SP KUBE Gakin" Program. There were 106 poor families getting loan in $1^{\text {st }}$ period and $2^{\text {nd }}$ period during fiscal year 2005 were drawn for this study. This research was conducted for 5 months (Juni until November 2006). Social capital was measured by 3 variables that are trust, networks, and norms. The improvement of family welfare of the "UEK-SP KUBE Gakin" was assessed by measuring of the changing of economic family condition after participated in that program. This research used Spearman Correlation Test to measure correlation between variables. The results showed that social capital had significant correlation with the increasing of poor family economic welfare of "UEK-SP KUBE Gakin" participants. Social capital variables that had significant correlation with the improvement of family welfare of participants were trust $(\alpha=0.01)$, "UEK-SP KUBE Gakin" rules $(\alpha=0.0)$, and networks $(\alpha=0.05)$.
\end{abstract}

Key Words: social capital, empowerment, poor family

\section{PENDAHULUAN}

Posisi Kota Bogor yang strategis sebagai penyangga ibukota negara, tidak menjadikannya sebagai wilayah yang bebas dari penduduk miskin. Pada tahun 2003, berdasarkan data Susenas BPS Jawa Barat, penduduk miskin Kota Bogor berjumlah 8.22\% (BPS Jabar 2003). Pada peluncuran dana Bantuan Langsung Tunai (BLT) periode I tahun 2005 , terdapat $19.52 \%$ rumah tangga yang mempunyai kategori miskin.

Berbagai program pengentasan kemiskinan, dengan berbagai istilahnya, telah banyak diselenggarakan untuk membantu masyarakat miskin di Kota Bogor. Program-program yang dilaksanakan ada yang bertujuan untuk memberdayakan ekonomi, membantu kebutuhan primer, maupun membantu kebutuhan pendidikan. Programprogram tersebut antara lain JPS
(Jaring Pengaman Sosial), P2KP (Program Pengentasan Kemiskinan Perkotaan), Prosustaskin (Program Khusus Pengentasan Kemiskinan), UEK-SP (Usaha Ekonomi Kelurahan Simpan Pinjam), Raskin (beras untuk keluarga miskin), pemberian beasiswa untuk AUS-KM (Anak Usia Sekolah Keluarga Miskin), lantainisasi rumah, perbaikan RTLH (Rumah Tidak Layak Huni), KUBE Gakin (Kelompok Usaha Bersama Keluarga Miskin), dan BLT (Bantuan Langsung Tunai). Programprogram tersebut dikoordinasikan baik oleh Pemerintah Pusat, Pemerintah Daerah Propinsi Jawa Barat maupun oleh Pemerintah Daerah Kota Bogor.

UEK-SP KUBE Gakin (Usaha Ekonomi Kelurahan-Simpan Pinjam Kelompok Usaha Bersama Keluarga Miskin) merupakan salah satu program yang dikoordinir oleh Dinas Tenaga Kerja dan Sosial (Disnakersos) Kota Bogor yang diselenggarakan sejak 
Tahun Anggaran 2005 dan bertujuan untuk memberdayakan ekonomi keluarga miskin. Dalam pengoptimalan pemberdayaan keluarga miskin melalui Kelompok Usaha Bersama (KUBE), seperti yang dilaksanakan oleh Pemda Kota Bogor tersebut, diperlukan perpaduan yang sinergis antara modal yang bersifat materi maupun non materi. Modal materi, baik berupa modal uang ataupun sarana dan prasarana, perlu dipadukan dengan modal non materi sehingga upaya pemberdayaan menuju kemandirian keluarga miskin dalam meningkatkan kesejahteraannya dapat lebih efektif. Salah satu modal non materi yang dimaksud adalah modal sosial. Modal sosial merupakan modal yang dimiliki oleh masyarakat sebagai hasil dari hubungan-hubungan sosial yang terjalin di antara sesama anggota masyarakat. Robert Putnam, salah seorang pelopor modal sosial menyebutkan bahwa modal sosial mempunyai tiga pilar utama sebagai aset dalam pengembangan masyarakat. Ketiga pilar ini adalah kepercayaan, norma dan nilai yang berlaku dalam masyarakat, serta jaringan sosial yang terjalin dalam sistem sosial (Winter 2000). Berbagai penelitian menunjukkan adanya keterkaitan yang erat antara modal sosial dengan peningkatan kesejahteraan masyarakat, khususnya kesejahteraan keluarga miskin.

Penelitian yang dilakukan di tiga provinsi di Indonesia (Jambi, Jawa Tengah, dan Nusa Tenggara Timur) menunjukkan bahwa rumah tangga yang memiliki modal sosial yang tinggi mempunyai kemampuan yang lebih baik dalam hal mengumpulkan aset fisik, menabung, dan memperoleh kredit guna meningkatkan kesejahteraannya (Grootaert 1999). Pendapat yang sama juga dikemukakan oleh Skidmore (2001) bahwa beberapa tipe modal sosial dapat berperan dalam mempercepat pertumbuhan ekonomi dan peningkatan kesejahteraan masyarakat
Penelitian ini bertujuan untuk mengetahui hubungan modal sosial dengan pemberdayaan ekonomi keluarga miskin melalui UEK-SP KUBE Gakin. Faktor modal sosial yang ditelaah meliputi kepercayaan (trust), jaringan sosial (networks), dan norma sosial (social norms).

\section{METODE PENELITIAN}

Desain, Tempat, dan Waktu Penelitian

Penelitian dilakukan di Kelurahan Kedung Jaya, Kecamatan Tanah Sareal, Kota Bogor. Penelitian ini diselesaikan dalam waktu 5 bulan, dimulai sejak Juni hingga November 2006. Desain penelitian yang digunakan dalam penelitian ini adalah cross sectional study.

\section{Penarikan Contoh}

Kerangka contoh penelitian ini adalah keluarga miskin yang diintervensi UEK-SP KUBE Gakin di Kelurahan Kedung Jaya, Kecamatan Tanah Sareal, Kota Bogor. Berdasarkan pendataan yang dilakukan oleh pengurus UEK-SP KUBE Gakin Kelurahan Kedung Jaya, terdapat 144 keluarga miskin yang sudah dan akan menjadi sasaran program ini sejak dimulainya program ini pada Juli 2005. Contoh penelitian ini adalah 106 keluarga miskin yang memperoleh pinjaman pada periode 1 dan 2 tahun anggaran 2005. Dana pada Periode 1 diluncurkan pada tanggal 23 Juli 2005 dan Periode 2 diluncurkan pada tanggal 22 November 2005.

\section{Jenis dan Cara Pengumpulan Data}

Jenis data yang akan dikumpulkan dalam penelitian ini adalah data primer dan data sekunder. Data primer dikumpulkan melalui wawancara dengan kepala keluarga (suami dan istri) dengan menggunakan instrumen kuesioner. Peneliti juga melakukan pengamatan langsung di lapang (observasi) untuk memperoleh datadata kualitatif guna mendukung analisis statistik yang dilakukan. Selain data primer, penelitian ini juga akan 
menggunakan data sekunder dari instansi-instansi terkait.

Kuesioner disusun secara berurutan mulai dari karakteristik keluarga, pendapatan dan pengeluaran keluarga, variabel modal sosial, dan perubahan kondisi ekonomi keluarga sesudah menjadi anggota KUBE Gakin. Pengukuran modal sosial dalam penelitian ini meliputi kepercayaan (trust), norma sosial (norms), dan jaringan sosial (networks). Kepercayaan (trust) dinilai dari enam aspek yaitu: (a) Tingkat kepercayaan diri keluarga anggota KUBE Gakin dalam menjalin hubungan di kelompoknya; (b) Tingkat kepercayaan antar keluarga anggota KUBE Gakin untuk bekerja sama; (c) Tingkat kepercayaan antar keluarga anggota KUBE Gakin bahwa kerja sama yang dilakukan dapat memudahkan pekerjaan; (d) Tingkat kepercayaan antar keluarga anggota KUBE Gakin terhadap aturan-aturan (aturan kelompok, nilai budaya, nilai agama) untuk menciptakan ketertiban jalannya kelompok; (e) Tingkat kepercayaan antar keluarga anggota KUBE Gakin untuk menjaga keeratan hubungan; dan (f) Tingkat kepercayaan antar keluarga anggota KUBE Gakin untuk menjamin kelompok secara berkelanjutan. Sementara itu, jaringan sosial dinilai dari luas jaringan, basis jaringan, kedalaman jaringan, dan permanency jaringan. Aspek norma sosial yang digunakan dalam penelitian ini adalah aturan-aturan yang dimiliki oleh KUBE Gakin yang mengatur hak dan kewajiban pengurus dan anggota KUBE Gakin.

Perubahan kondisi ekonomi keluarga sesudah menjadi anggota KUBE Gakin dinilai dari pendapat subjektif responden terhadap keadaan ekonomi mereka sesudah menjadi anggota KUBE Gakin yang dikategorikan menjadi : (1) jauh lebih buruk saat ini; (2) sedikit lebih buruk saat ini; (3) tidak ada perubahan apaapa; (4) sedikit lebih baik saat ini; dan (5) jauh lebih baik saat ini.
Pengolahan dan Analisis Data Data yang diperoleh selanjutnya diolah dengan menggunakan analisis statistik dan dalam penyajiannya akan ditambahkan pendeskripsiannya. Analisis statistik yang dipakai dalam penelitian ini menggunakan tabulasi silang dan uji korelasi Spearman untuk melihat hubungan antar variabel. Uji korelasi Spearmen dipilih karena data yang diperoleh dalam penelitian ini merupakan data kategori (ordinal).

\section{HASIL DAN PEMBAHASAN}

Karakteristik Keluarga Miskin

Kondisi ekonomi keluarga dalam penelitian ini dikelompokkan dengan pendekatan pengeluaran karena dinilai lebih mendekati kondisi riil keluarga miskin. Sementara itu, jenis-jenis pekerjaan utama yang dimiliki oleh kepala keluarga miskin di lokasi penelitian antara lain pedagang $(29.2 \%)$, buruh $(29.2 \%)$, tukang bangunan (7.5\%), tukang becak $(1.9 \%)$, sopir angkot $(4.7 \%)$, tukang delman $(2.8 \%)$, bengkel $(1.9 \%)$, penjahit $(0.9 \%)$, pemulung $(0.9 \%)$, dan guru ngaji (0.9\%). Sementara bagi keluarga miskin yang kepala keluarganya perempuan, alternatif lain jenis pekerjaan utama adalah pembantu rumah tangga termasuk sebagai tukang cuci. Hanya 7,5\% responden yang bekerja sebagai karyawan dengan penghasilan tetap setiap bulannya. Kondisi tersebut menggambarkan bahwa jenis pekerjaan yang dimiliki kepala keluarga miskin merupakan jenis pekerjaan yang tidak mempunyai penghasilan tetap setiap bulannya.

Oleh karenanya, kondisi sosial ekonomi keluarga responden dalam penelitian ini dihitung dengan menggunakan pendekatan pengeluaran. Gambar 1 menunjukkan bahwa sebagian besar responden keluarga miskin dalam penelitian ini mempunyai rata-rata pengeluaran setiap bulannya antara Rp $600,000.00$ - Rp 900,000.00. Apabila dibandingkan antara keluarga yang KK-nya laki-laki 
dan perempuan terlihat bahwa keluarga dengan KK perempuan, mempunyai rata-rata pengeluaran setiap bulannya lebih rendah daripada keluarga yang mempunyai KK laki-laki.

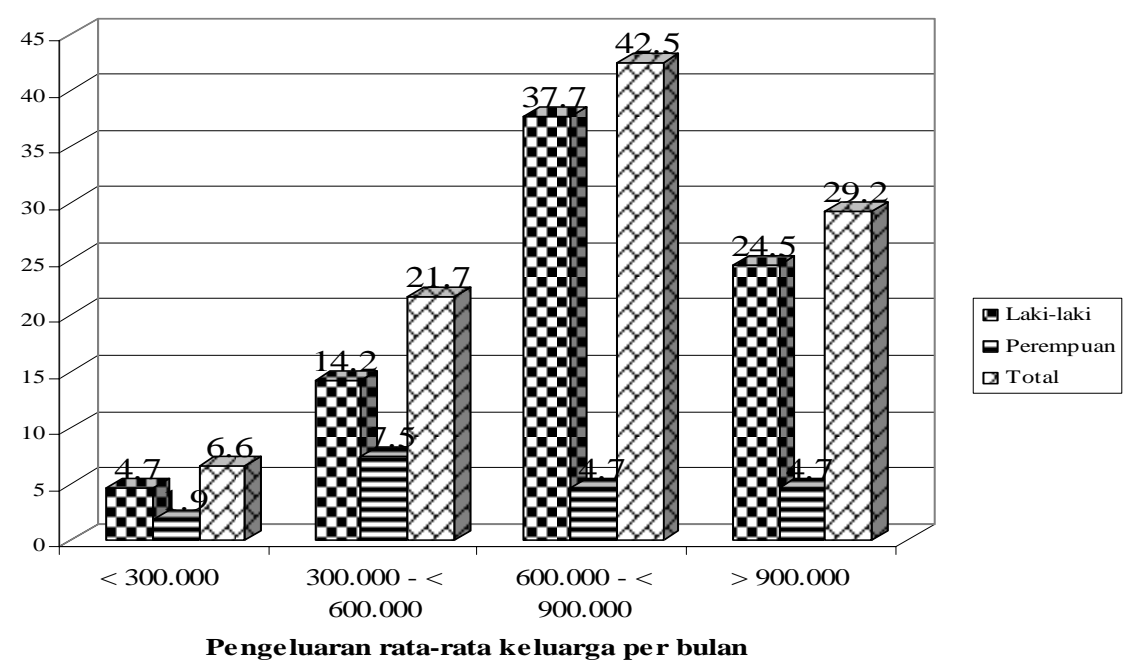

Gambar 1. Besar Pengeluaran Rata-rata Keluarga per Bulan berdasarkan Jenis Kelamin Kepala Keluarga

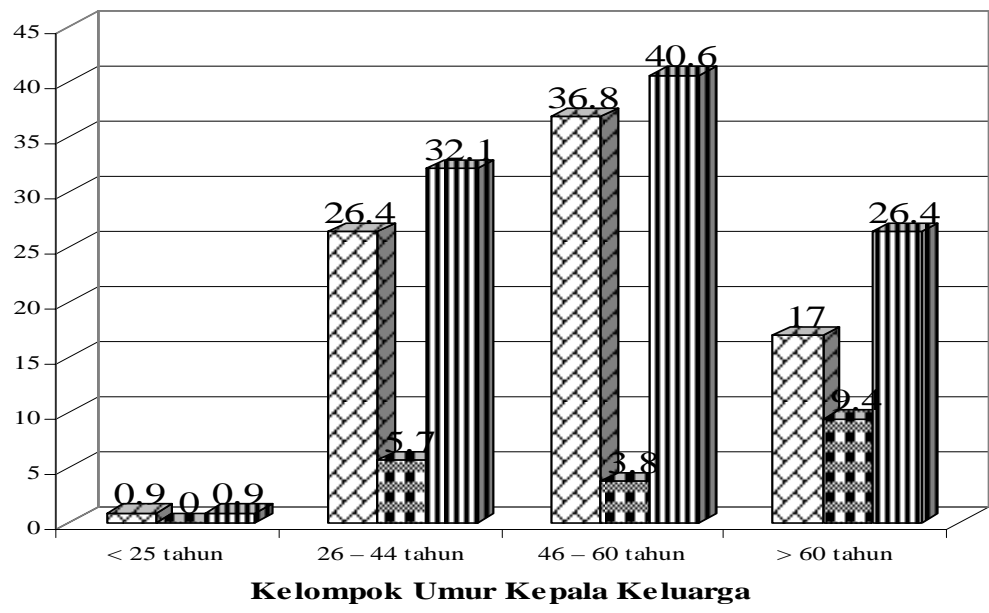

Gambar 2. Kelompok Umur Kepala Keluarga berdasarkan Jenis Kelamin Kepala Keluarga

Sebaran jenis kelamin kepala keluarga responden berdasarkan umur disajikan pada Gambar 2. Gambar 2 menunjukkan bahwa berdasarkan umur kepala keluarga sebagian besar kepala keluarga $(40.6 \%)$ berada dalam kelompok umur antara 45 - 60 tahun dan paling sedikit adalah kepala keluarga dengan usia $<25$ tahun
(0.9\%). Kondisi tersebut menunjukkan bahwa sebagian besar keluarga responden mempunyai kepala keluarga dalam usia produktif. Keberadaan usia produktif dalam keluarga memberikan peluang bagi keluarga untuk meningkatkan potensinya guna meningkatkan pendapatan. Keberadaan kepala keluarga yang 
sebagian besar berada dalam usia produktif mengindikasikan bahwa supply sumberdaya manusia berupa tenaga kerja tersedia di dalam keluarga. Sehingga aktivitas ekonomi berupa produksi, distribusi, maupun konsumsi memungkinkan berlangsung secara menyeluruh di dalam keluarga.

Keluarga dengan KK perempuan paling banyak berada dalam kelompok umur > 60 tahun (9.4\%). Hal ini kemungkinan disebabkan suami telah meninggal dunia (Gambar 2).

Sementara itu, bila ditinjau dari segi pendidikan sebagian besar kepala keluarga (60.4\%) mempunyai pendidikan tamat SD atau sederajat. Jumlah paling sedikit adalah keluarga dengan kepala keluarga berpendidikan perguruan tinggi (1.9\%). Kondisi tersebut menunjukkan bahwa bukan hanya kondisi ekonomi yang rendah saja yang dihadapi keluarga miskin, namun juga rendahnya tingkat pendidikan. Hal ini menunjukkan bahwa kemiskinan merupakan masalah yang multidimensional dan program-program untuk mengentaskannya bukan hanya untuk memperbaiki kondisi ekonomi namun juga pendidikan maupun kapasitas sosial. Keterbatasan kemampuan ekonomi yang dimiliki oleh keluarga miskin telah menyebabkan terbatasnya daya untuk memperoleh pendidikan, pangan, maupun sarana kesehatan. Sehingga bila pengentasan kemiskinan tidak dilakukan melalui program yang komprehensif maka kesejahteraan dan kapasitas keluarga miskin tidak akan meningkat secara menyeluruh.

Pada Tabel 1 disajikan jumlah anggota keluarga responden. Keluarga paling banyak adalah keluarga dengan jumlah anggota antara 4-6 orang $(62.2 \%)$. Bila dilakukan uji korelasi Spearman antara kategori jumlah anggota keluarga dengan kategori pengeluaran keluarga diperoleh koefisien korelasi $0.426^{* \star}$ pada $\alpha=0.01$.
Koefisien tersebut menunjukkan kecenderungan bahwa semakin banyak anggota keluarga maka semakin besar pengeluaran keluarga setiap bulannya. Peningkatan pengeluaran keluarga seiring dengan meningkatnya jumlah anggota keluarga yang dimiliki, apabila tidak diikuti dengan peningkatan pendapatan keluarga maka peningkatan kesejahteraan ekonomi keluarga miskin pun akan sulit dicapai.

Bila pendapatan keluarga tetap, penambahan jumlah anggota keluarga akan menyebabkan peningkatan pengeluaran keluarga. Sehingga kemungkinan besar akan menyebabkan lebih besarnya pengeluaran keluarga dibandingkan dengan pendapatannya. Untuk meningkatkan pendapatan keluarga bukan hal yang mudah bila hanya mengandalkan penghasilan dari mata pencahariaan sehari-hari. Seperti yang telah diuraikan sebelumnya, kecenderungan jenis pekerjaan yang dimiliki kepala keluarga adalah jenis pekerjaan yang menghasilkan pendapatan secara tidak tetap. Alih-alih meningkatkan pendapatan, untuk memperoleh kepastian bahwa bulan tersebut keluarga mempunyai penghasilan saja sulit diprediksikan.

Tabel 1. Sebaran Jumlah Anggota Keluarga

\begin{tabular}{|c|c|c|c|c|c|}
\hline \multirow{2}{*}{\multicolumn{2}{|c|}{$\begin{array}{c}\text { Pengeluaran } \\
\text { keluarga } \\
\text { (Rp/bulan) }\end{array}$}} & \multirow{2}{*}{\multicolumn{3}{|c|}{$\begin{array}{c}\text { Jumlah } \\
\text { anggota } \\
\text { keluarga } \\
\text { (orang) }\end{array}$}} & \multirow{3}{*}{$\begin{array}{l}\text { Total } \\
\\
\\
7 \\
\end{array}$} \\
\hline & & & & & \\
\hline & & \multirow{2}{*}{$\begin{array}{r}<4 \\
3\end{array}$} & \multirow{2}{*}{\begin{tabular}{c|}
$4-$ \\
6 \\
4
\end{tabular}} & \multirow{2}{*}{$\begin{array}{r}>6 \\
0\end{array}$} & \\
\hline$<300,000.00$ & $\mathrm{n}$ & & & & \\
\hline & $\%$ & 2.8 & 3.8 & 0.0 & 6.6 \\
\hline $300,000.00-$ & $\mathrm{n}$ & 11 & 12 & 0 & 23 \\
\hline$<600,000.00$ & $\%$ & 10.4 & 11.3 & 0.0 & 21.7 \\
\hline $600,000.00-$ & $\mathrm{n}$ & 9 & 30 & 6 & 45 \\
\hline$<900,000.00$ & $\%$ & 8.5 & 28.3 & 5.7 & 42.5 \\
\hline$\geq 900,000.00$ & $\mathrm{n}$ & 2 & 20 & 9 & 31 \\
\hline & $\%$ & 1.9 & 18.9 & 8.5 & 29.2 \\
\hline TOTAL & $\mathrm{n}$ & 25 & 66 & 15 & 106 \\
\hline
\end{tabular}


Pemberdayaan Ekonomi Anggota UEKSP KUBE Gakin

Sasaran Program UEK-SP KUBE Gakin adalah keluarga, namun dengan pendekatan kelompok. Pendekatan pengembangan ekonomi kelompok merupakan salah satu bentuk pengembangan ekonomi komunitas yang perlu mendapat perhatian yang cukup besar antara tujuan siapa yang ingin dicapai dari komunitas dan siapa yang mencapai tujuan tersebut dalam komunitas. Menurut Shaffer dan Summers dalam Christenson dan Robinson Jr. (1989), tujuan dari pengembangan ekonomi komunitas adalah untuk menciptakan pekerjaanpekerjaan yang sesuai dan mampu menghasilkan pendapatan riil bagi penduduk setempat, sehingga lokalitas menjadi unsur penting dalam strategi ini. Dalam penelitian ini, jenis-jenis usaha kecil yang dilakukan oleh keluarga responden disajikan pada Tabel 2.

Seperti yang tersaji pada Tabel 2, jenis usaha yang banyak dilakukan keluarga dengan dana pinjaman yang diperoleh dari UEK-SP KUBE Gakin adalah usaha niaga. Mulai dari jual makanan, jual baju/kain, jual kosmetik, jual rokok, jual minyak tanah, jual oli, hingga barang bekas. Usaha-usaha niaga yang dilakukan oleh para keluarga miskin penerima pinjaman UEK-SP KUBE Gakin di Kelurahan Kedung Jaya ada yang merupakan usaha yang memang dari dulu menjadi sumber penghasilan keluarga namun ada juga usaha yang baru saja dilakukan keluarga setelah menerima pinjaman. Sebagai contoh, terdapat satu keluarga responden yang dulunya istrinya bekerja sebagai Sales Promotion Girl (SPG). Berhubung sudah tidak bekerja lagi sebagai SPG maka istri di keluarga tersebut membuka usaha gorengan dari modal yang dipinjamkan oleh program UEK SP-KUBE Gakin. Sementara itu, usaha-usaha kecil yang dimiliki keluarga di luar usaha niaga seperti bengkel, penjahit, maupun tukang becak merupakan usaha yang memang sudah diusahakan keluarga sebelum memperoleh pinjaman dari program UEK-SP KUBE Gakin.

Tabel 2. Jenis Usaha Ekonomi yang Diusahakan Keluarga dari Modal Pinjaman UEK-SP KUBE Gakin

\begin{tabular}{|c|c|c|c|c|}
\hline \multirow{2}{*}{\multicolumn{2}{|c|}{$\begin{array}{c}\text { Jenis usaha } \\
\text { ekonomi } \\
\text { yang } \\
\text { dilakukan }\end{array}$}} & \multicolumn{2}{|c|}{ Pelaku usaha } & \multirow{3}{*}{$\begin{array}{c}\text { Total } \\
\\
75 \\
\end{array}$} \\
\hline & & \multirow{2}{*}{$\begin{array}{c}\begin{array}{c}\text { Keluarga } \\
\text { inti KK }\end{array} \\
74\end{array}$} & \multirow{2}{*}{$\begin{array}{c}\text { Luar } \\
\text { keluarga } \\
\text { inti KK }\end{array}$} & \\
\hline \multirow{2}{*}{$\begin{array}{l}\text { Jual } \\
\text { makanan }\end{array}$} & $\mathrm{n}$ & & & \\
\hline & $\%$ & 69.8 & 0.9 & 70.8 \\
\hline \multirow{2}{*}{$\begin{array}{l}\text { Jual } \\
\text { baju/kain }\end{array}$} & $\mathrm{n}$ & 5 & 0 & 5 \\
\hline & $\%$ & 4.7 & 0.0 & 4.7 \\
\hline \multirow{2}{*}{$\begin{array}{l}\text { Jual } \\
\text { kosmetik }\end{array}$} & $\mathrm{n}$ & 2 & 1 & 3 \\
\hline & $\%$ & 1.9 & 0.9 & 2.8 \\
\hline \multirow{2}{*}{$\begin{array}{l}\text { Jual } \\
\text { rokok }\end{array}$} & $\mathrm{n}$ & 5 & 0 & 5 \\
\hline & $\%$ & 4.7 & 0.0 & 4.7 \\
\hline \multirow{2}{*}{$\begin{array}{l}\text { Jual } \\
\text { minyak } \\
\text { tanah }\end{array}$} & $\mathrm{n}$ & 2 & 0 & 2 \\
\hline & $\%$ & 1.9 & 0.0 & 1.9 \\
\hline \multirow[t]{2}{*}{ Jual oli } & $\mathrm{n}$ & 2 & 0 & 2 \\
\hline & $\%$ & 1.9 & 0.0 & 1.9 \\
\hline \multirow{2}{*}{$\begin{array}{l}\text { Jual } \\
\text { bunga }\end{array}$} & $\mathrm{n}$ & 1 & 0 & 1 \\
\hline & $\%$ & 0.9 & 0.0 & 0.9 \\
\hline \multirow{2}{*}{$\begin{array}{l}\text { Jual } \\
\text { barang } \\
\text { bekas }\end{array}$} & $\mathrm{n}$ & 1 & 0 & 1 \\
\hline & $\%$ & 0.9 & 0.0 & 0.9 \\
\hline \multirow[t]{2}{*}{ Penjahit } & $\mathrm{n}$ & 1 & 0 & 1 \\
\hline & $\%$ & 0.9 & 0.0 & 0.9 \\
\hline \multirow[t]{2}{*}{ Bengkel } & $\mathrm{n}$ & 1 & 2 & 3 \\
\hline & $\%$ & 0.9 & 1.9 & 2.8 \\
\hline \multirow[t]{2}{*}{ Becak } & $\mathrm{n}$ & 1 & 0 & 1 \\
\hline & $\%$ & 0.9 & 0.0 & 0.9 \\
\hline \multirow{2}{*}{$\begin{array}{l}\text { Tidak } \\
\text { usaha } \\
\text { lagi }\end{array}$} & $\mathrm{n}$ & 7 & 0 & 7 \\
\hline & $\%$ & 6.6 & 0.0 & 6.6 \\
\hline \multirow[t]{2}{*}{ TOTAL } & $\mathrm{n}$ & 102 & 4 & 106 \\
\hline & $\%$ & 96.2 & 3.8 & 100 \\
\hline
\end{tabular}

Sumber : Data Primer Diolah (2006)

Informasi yang tersaji pada Tabel 2 menunjukkan bahwa terdapat 7 keluarga $(6,6 \%)$ yang sudah tidak lagi meneruskan usahanya. Keluarga yang tidak meneruskan usahanya tersebut adalah keluarga yang memperoleh pinjaman pada Periode 1 dan sudah selesai. Lima dari tujuh keluarga yang usahanya tidak berlanjut juga 
memperoleh pinjaman kembali pada Periode 2. Pinjaman UEK-SP KUBE Gakin adalah sebesar Rp 300.000,yang dikembalikan dalam jangka waktu 10 (sepuluh) bulan. Keluarga-keluarga yang tidak meneruskan usahanya tersebut mengindikasikan bahwa usaha ekonomi yang dilakukannya tidak berjalan secara sustainable. Bahkan meskipun sudah memperoleh pinjaman selama dua periode, usaha ekonomi yang dijalankan keluarga dengan modal pinjaman dari UEK-SP KUBE Gakin tetap tidak dapat berlanjut.

Apabila dianalisis dengan konsep Shaffer dan Summers (Christenson dan Robinson Jr. 1989) bahwa lokalitas menjadi unsur penting dalam pengembangan ekonomi komunitas untuk menciptakan pekerjaanpekerjaan yang sesuai dan mampu menghasilkan pendapatan riil bagi penduduk setempat, maka bila usahausaha yang dipunyai keluarga adalah usaha ekonomi yang sifatnya melanjutkan usaha ekonomi keluarga, dapat disimpulkan bahwa strategi lokalitas telah diterapkan oleh kelompok ini. Namun tentu saja, keberhasilan pengembangan ekonomi komunitas dengan sasaran keluarga miskin tidak hanya ditentukan oleh usaha ekonomi berbasis lokalitas saja. Lebih lanjut, apakah usaha-usaha ekonomi yang sudah dikembangkan secara lokalitas tersebut mampu meningkatkan pendapatan riil anggota kelompok atau belum. Hal inilah yang penting untuk menentukan apakah suatu program pemberdayaan ekonomi dikatakan berhasil atau tidak.

Penelitian ini menunjukkan bahwa sebagian besar keluarga responden, baik yang kepala keluarganya laki-laki ataupun perempuan, mengaku bahwa kondisi ekonomi keluarga tidak mengalami perubahan sebelum maupun sesudah menjadi anggota kelompok. Hanya 7,5\% keluarga responden yang mengaku bahwa kondisi ekonomi keluarga mereka sedikit lebih baik sesudah menjadi anggota kelompok UEK-SP KUBE
Gakin. Keadaan ini dapat disebabkan oleh beberapa faktor antara lain, pertama, karena usaha ekonomi yang dilakukan sebagian besar keluarga responden merupakan usaha ekonomi yang memang sudah dimiliki keluarga dan merupakan usaha kecil (sebagian besar jual makanan seperti gorengan, bubur, dll) maka tidak ada perbedaan pendapatan sebelum dan sesudah menjadi anggota kelompok. Kedua, meskipun pendapatan meningkat namun bila harga barang-barang faktor produksi juga meningkat maka daya beli keluarga akan menjadi tetap. Dengan kata lain, pendapatan riil keluarga tidak meningkat. Hal ini menyebabkan keluarga tidak merasakan keadaan ekonomi menjadi lebih baik dari sebelumnya. Sehingga bila merujuk pada Shaffer dan Summers (Christenson dan Robinson Jr. 1989), UEK-SP KUBE Gakin di Kelurahan Kedung Jaya ini belum mampu menciptakan pekerjaanpekerjaan yang meningkatkan pendapatan riil anggotanya.

Menurut Christenson dan Robinson Jr. (1989), kekuatan dari pengembangan ekonomi kelompok berbasis komunitas adalah : (a) penggunaan secara efektif sumber daya yang ada dalam kelompok (komunitas); (b) pemeliharaan sumberdaya-sumberdaya tersebut dalam jangka waktu yang panjang; dan (c) kemampuan kelompok (komunitas) untuk menyesuaikan diri dalam menghadapi kondisi yang senantiasa berubah. Ketiga hal ini tentu saja akan membawa dampak yang cukup luas terhadap pelaksanaan pengembangan ekonomi kelompok (komunitas).

Adanya keluarga yang usaha ekonominya tidak berkelanjutan menunjukkan bahwa ketiga kekuatan pengembangan ekonomi kelompok tersebut belum optimal. Terbukti bahwa ada anggota kelompok yang tidak mampu memelihara sumberdayasumberdaya yang dimiliki (dalam hal ini usaha ekonomi dan modal) dalam jangka waktu yang panjang. Dari hasil

Vol. 1 No. 1/Januari 2008 - 35 
wawancara mendalam, ketika ditanya alasan mengapa usaha ekonominya tidak berlanjut terdapat responden yang menjawab dikarenakan uang pinjaman yang diperoleh dari UEK-SP KUBE Gakin digunakan untuk memenuhi kebutuhan sehari-hari. Hal tersebut menunjukkan bahwa terdapat anggota kelompok yang tidak dapat menyesuaikan diri dalam menghadapi kondisi yang berubah. Kontrol dari pengurus pun kelihatannya tidak berjalan optimal. Hal ini dapat dilihat pada keluarga yang dua kali memperoleh pinjaman meskipun pada Periode 1 sebenarnya usahanya sudah tidak berlanjut.

Keterkaitan Modal Sosial dalam Peningkatan Kesejahteraan Keluarga Miskin melalui UEK-SP KUBE Gakin

Pada awal munculnya konsep modal sosial, oleh sosiolog Pierre Bourdieu, modal sosial didefinisikan sebagai sumberdaya baik yang aktual maupun maupun potensial yang dimiliki seseorang berkat adanya jaringan hubungan secara kelembagaan yang terpelihara dengan baik (Syahra et al. 2000). Robert Putnam, salah satu pelopor modal sosial, mendefinisikan modal sosial sebagi pendorong dalam kelembagaan demokrasi dan pengembangan ekonomi. Putnam mendefinisikan modal sosial sebagai kepercayaan (trust), norma (norms), dan jaringan (networks) yang memfasilitasi adanya kerjasama untuk mencapai keuntungan bersama. (Winter 2000).

Tingkat Kepercayaan di Dalam Kelompok. Mollering menyebutkan bahwa modal sosial mempunyai enam fungsi penting yaitu : (1) Kepercayaan dalam arti confidence yang merupakan ranah psikologis individual sebagai sikap yang akan mendorong seseorang dalam mengambil keputusan setelah menimbang resiko yang akan diterima.; (2) Kerja sama yang menempatkan trust sebagai dasar hubungan antar individu tanpa rasa saling curiga;
Penyederhanaan pekerjaan yang memfungsikan trust sebagai sumber untuk membantu meningkatkan efisiensi dan efektivitas kerja kelembagaan-kelembagaan sosial; (4) Ketertiban dimana trust sebagai inducing behaviour setiap individu untuk menciptakan kedamaian dan meredam kekacauan sosial; Pemelihara kohesivitas sosial yang membantu merekatkan setiap komponen sosial yang hidup dalam komunitas menjadi kesatuan; (6) Trust sebagai modal sosial yang menjamin struktur sosial berdiri secara utuh dan berfungsi secara operasional serta efisien (Dharmawan 2002a; 2002b). Tabel 3 berikut ini menyajikan sebaran tingkat kepercayaan responden dengan mengacu pada pendapat Mollering.

Hasil yang tersaji pada Tabel 3 menunjukkan bahwa kepercayaan, sebagai salah satu komponen modal sosial, berada dalam taraf sedang. Sehingga akan ada dua kemungkinan yang terjadi. Bila program UEK-SP ke depan tidak mampu menumbuhkan tingkat kepercayaan anggota kelompok maka akan mengindikasikan pudarnya salah satu komponen modal sosial. Pudarnya tingkat kepercayaan antar anggota akan menyebabkan hilangnya penggerak dalam menjalankan kelompok. Antar anggota akan cenderung saling curiga dan selanjutnya akan menghambat berjalannya kelompok. Namun, bila kepercayaan antar anggota maupun antar anggota dengan pengurus dapat terus ditingkatkan, maka akan menjadi modal potensial bagi kelompok untuk berkembang optimal dalam rangka mencapai tujuan bersam ameningkatkan kesejahteraan anggotanya. 
Tabel 3. Sebaran Tingkat

Kepercayaan Responden

\begin{tabular}{|c|c|c|c|}
\hline \multirow{2}{*}{$\begin{array}{c}\text { Jenis } \\
\text { kepercayaan }\end{array}$} & \multicolumn{3}{|c|}{ Jumlah (\%) } \\
\hline & Rendah & Sedang & Tinggi \\
\hline $\begin{array}{l}\text { Kepercayaan } \\
\text { diri keluarga } \\
\text { untuk menjalin } \\
\text { hubungan sosial }\end{array}$ & 0.9 & 56.6 & 23.6 \\
\hline $\begin{array}{l}\text { Kepercayaan } \\
\text { bahwa anggota } \\
\text { kelompok dapat } \\
\text { bekerjasama } \\
\text { tanpa rasa } \\
\text { saling curiga }\end{array}$ & 0.9 & 60.4 & 19.8 \\
\hline $\begin{array}{l}\text { Kepercayaan } \\
\text { bahwa } \\
\text { kerjasama yang } \\
\text { terjalin dapat } \\
\text { meningkatkan } \\
\text { pendapatan }\end{array}$ & 0.9 & 57.5 & 22.6 \\
\hline $\begin{array}{l}\text { Kepercayaan } \\
\text { bahwa } \\
\text { kerjasama yang } \\
\text { terjalin dapat } \\
\text { melancarkan } \\
\text { usaha ekonomi }\end{array}$ & 0.9 & 56.6 & 23.6 \\
\hline $\begin{array}{l}\text { Kepercayaan } \\
\text { bahwa aturan } \\
\text { kelompok dapat } \\
\text { menertibkan } \\
\text { jalannya } \\
\text { kelompok }\end{array}$ & 0.9 & 56.6 & 23.6 \\
\hline $\begin{array}{l}\text { Kepercayaan } \\
\text { bahwa menjaga } \\
\text { keeratan } \\
\text { hubungan } \\
\text { penting }\end{array}$ & 0.9 & 52.8 & 27.4 \\
\hline $\begin{array}{l}\text { Kepercayaan } \\
\text { menjaga } \\
\text { hubungan dan } \\
\text { usaha ekonomi } \\
\text { tetap sustain }\end{array}$ & 0.9 & 57.5 & 22.6 \\
\hline
\end{tabular}

Sumber : Data primer diolah (2006)

Jaringan Sosial. Menurut Stone dan Hughes (2002), modal sosial mempunyai dua ukuran utama yaitu : (1) jaringan sosial (networks) dan (2) karakteristik jaringan sosial (networks characteristics). Jaringan sosial dilihat dengan menggunakan beberapa ukuran yaitu: (a) ikatan informal yang dikarakteristikan dengan adanya kepercayaan dan hubungan timbal balik yang lebih familiar dan bersifat personal seperti pada ikatan pada keluarga, pertemanan, pertetanggaan; (b) ikatan yang sifatnya lebih umum seperti ikatan pada masyarakat setempat, masyarakat umum, masyarakat dalam kesatuan kewarganegaraan. Ikatan ini dikarakteristikkan dengan adanya kepercayaan dan hubungan timbal balik yang sifatnya umum; dan (c) ikatan kelembagaan yang dikarakteristikkan dengan adanya kepercayaan dalam kelembagaan yang ada. Sementara itu, karakteristik jaringan sosial (network characteristics) dapat dilihat dari tiga karakteristik yaitu : bentuk dan luas (size and extensiveness), kerapatan dan ketertutupan (density and closure), dan keragaman (diversity).

Hasil penelitian ini menunjukkan bahwa semua keluarga responden $(100 \%)$ mengaku mempunyai jaringan sosial yang informal. Kondisi ini dikarenakan ikatan pertetanggan dan ikatan kekerabatan yang masih kental di lingkungan Kelurahan Kedung Jaya, Kecamatan Tanah Sareal dan menjadi basis jaringan utama responden dalam kehidupan sehari-hari maupun dalam menjalankan usaha. Jaringan sosial informal yang ada dapat merupakan potensi yang besar dalam mengembangkan kelompok. Ikatan yang lebih personal membuat hubungan-hubungan sosial antar anggota kelompok menjadi lebih dekat dan dapat dimanfaatkan untuk mengeksplorasi upaya-upaya yang dibutuhkan kelompok untuk mengoptimalkan usaha ekonomi anggotanya. Hanya saja, hubungan sosial dengan pihak di luar kelompok belum terjalin dengan baik. Hasil penelitian ini menunjukkan bahwa $88.7 \%$ keluarga responden hanya mempunyai hubungan sosial kurang dari 5 pihak di luar kelompok dalam usaha ekonominya. Hal ini tentu saja akan menjadi hambatan bagi pengembangan kelompok bila tidak dilakukan upaya-upaya untuk memperluas jaringan. Anggota kelompok akan cenderung menjalin hubungan sosial yang itu-itu saja sehingga jaringan tidak akan meluas. Padahal jaringan yang lebih luas berpotensi untuk mengembangkan usaha ekonomi yang ada. 
Tabel 4 berikut ini menyajikan karakteristik jaringan yang dimiliki anggota kelompok terkait dengan usaha ekonomi yang dilakukan, yang meliputi basis jaringan, luas, kedalaman jaringan, dan permanency jaringan. Karakteristik jaringan lainnya, yaitu keterbukaan jaringan menunjukkan bahwa baik anggota maupun kelompok mempunyai keterbukaan yang luas kepada pihak mana pun yang akan berinteraksi dengan mereka.

Tabel 4. Sebaran Jaringan Sosial Responden

\begin{tabular}{|c|c|c|c|}
\hline \multirow{2}{*}{$\begin{array}{l}\text { Karakteristik } \\
\text { jaringan }\end{array}$} & \multicolumn{3}{|c|}{ Jumlah (\%) } \\
\hline & Rendah & Sedang & Tingqi \\
\hline Luas jaringan & 0,0 & 82,1 & 17,9 \\
\hline $\begin{array}{l}\text { Kedalaman } \\
\text { jaringan anggota } \\
\text { dengan pengurus }\end{array}$ & 0,0 & 93,4 & 6,6 \\
\hline \begin{tabular}{lr}
\multicolumn{3}{l}{ Kedalaman } \\
jaringan anggota \\
KUBE & Gakin \\
dengan anggota \\
lain \\
sekelompok yang
\end{tabular} & 0,0 & 91,5 & 8,5 \\
\hline \begin{tabular}{l}
\multicolumn{2}{l}{ Kedalaman } \\
jaringan anggota \\
KUBE Gakin \\
dengan anggota \\
lain yang berbeda \\
kelompok
\end{tabular} & 0,0 & 91,5 & 8,5 \\
\hline $\begin{array}{l}\text { Kedalaman } \\
\text { jaringan anggota } \\
\text { dengan } \\
\text { komunitasnya }\end{array}$ & 0,0 & 93,4 & 6,6 \\
\hline $\begin{array}{l}\text { Permanency } \\
\text { jaringan }\end{array}$ & 0,0 & 0,9 & 99,1 \\
\hline
\end{tabular}

Sumber : Data primer diolah (2006)

Data yang tersaji pada Tabel 4 menunjukkan bahwa karakteristik jaringan berupa luas jaringan dan kedalaman jaringan sebagian besar responden berada dalam kategori sedang. Sementara itu, permanency jaringan sebagian besar responden berada dalam kategori tinggi. Hal ini dikarenakan anggota kelompok menetap sebagai penduduk di Kelurahan Kedung Jaya, sehingga kemungkinan besar jaringan sosial yang ada akan permanen meskipun tidak lagi menjadi anggota kelompok. Hanya saja, luas dan kedalaman jaringan yang dimiliki anggota kelompok bila tidak dapat dikembangkan maka kelompok maupun usaha ekonomi yang dimiliki oleh anggota keluarga tidak akan berkembang secara optimal.

Norma Sosial. Fedderke et al. (1999) menyatakan bahwa sebuah asosiasi sosial (organisasi sosial) di dalamnya mengandung norma-norma berupa aturan-aturan informal dan nilai-nilai yang memfasilitasi adanya koordinasi di antara anggota dalam sebuah sistem sosial. Hal ini menurutnya memungkinkan adanya tindakan-tindakan kerja sama dalam memudahkan pekerjaan guna mencapai keuntungan kolektif yang dirasakan bersama. Fukuyama (2001) norma-norma sosial yang menjadi komponen modal sosial misalnya kejujuran, sikap menjaga komitmen, pemenuhan kewajiban, ikatan timbal balik dan yang lainnya. Norma-norma sosial seperti ini sebenarnya merupakan aturan tidak tertulis dalam sebuah sistem sosial yang mengatur masyarakat untuk berperilaku dalam interaksinya dengan orang lain.

Dalam penelitian ini, keberadaan norma sosial yang dilihat meliputi norma tertulis, norma tidak tertulis, norma (nilai-nilai) tradisional, dan norma (nilai-nilai) keagamaan. Penelitian ini menunjukkan bahwa semua keluarga responden (100\%) mengaku di dalam kelompok tidak terdapat norma tidak tertulis, norma (nilai-nilai) tradisional, dan norma (nilainilai) keagamaan yang disepakati bersama. Hanya ada aturan-aturan tertulis terkait dengan hak dan kewajiban anggota kelompok saja yang diketahui oleh anggota kelompok ada di dalam kelompok. Meskipun ada aturan tertulis di dalam kelompok, hanya $24 ., 5 \%$ keluarga responden yang mengaku mengetahui dengan pasti aturan-aturan tertulis yang ada di dalam kelompok. Sisanya, $74.5 \%$ keluarga responden tidak terlalu yakin mengetahui adanya aturan tertulis di dalam kelompok. 
Nilai-nilai seperti kejujuran, sikap menjaga komitmen, pemenuhan kewajiban, ikatan timbal balik seperti yang disebutkan Fukuyama belum dirasakan sepenuhnya oleh anggota kelompok. Kondisi yang ada menunjukkan bahwa norma yang ada di kelompok tingkatannya masih rendah, baik dari keberadaan norma itu sendiri maupun pengetahuan dan kesadaran anggota akan norma yang ada. Padahal norma dapat menjadi pendorong tindakan-tindakan kerja sama dalam memudahkan pekerjaan guna mencapai keuntungan kolektif yang dirasakan bersama.

Keterkaitan Modal Sosial dengan Kondisi Kesejahteraan Ekonomi Anggota Kelompok. Peningkatan kesejahteraan diukur dari penilaian subyektif responden terhadap manfaat ekonomi yang diperoleh setelah menjadi anggota UEK-SP KUBE Gakin (Tabel 5). Koefisien korelasi yang dihasilkan dalam penelitian ini secara signifikan pada $\alpha=0.01$ menunjukkan bahwa variabel-variabel kepercayaan yang meliputi kepercayaan diri keluarga untuk menjalin hubungan (0.321), kepercayaan untuk menjalin kerjasama (0.351), kepercayaan bahwa kerjasama yang terjalin akan menguntungkan baik bagi peningkatan pendapatan keluarga maupun kelancaran usaha (0.314), kepercayaan akan peran aturan dalam menertibkan kelompok (0.388), kepercayaan untuk menjaga keeratan (0.367), dan kelanggengan hubungan (0.404) mempunyai hubungan erat secara positif dengan peningkatan kesejahteraan ekonomi keluarga anggota UEK-SP Kube Gakin. Sehingga bila kepercayaan di dalam kelompok ditingkatkan maka kesejahteraan ekonomi keluarga anggota UEK-SP Kube Gakin akan cenderung meningkat. Sehingga meningkatkan dan menumbuhkan rasa kepercayaan di dalam keluarga maupun di dalam kelompok senantiasa dibutuhkan, bukan hanya untuk memperbaiki hubungan sosial yang ada namun terbukti secara nyata berhubungan positif dengan kesejahteraan ekonomi keluarga anggota UEK-SP Kube Gakin.

Tabel 5. Hasil Uji Korelasi Variabel-variabel Modal Sosial dengan Variabel Peningkatan Kesejahteraan Ekonomi Responden Sesudah menjadi Anggota KUBE Gakin

\begin{tabular}{|c|c|}
\hline Hubungan antar variabel & $\begin{array}{l}\text { Koefisien } \\
\text { Spearman }\end{array}$ \\
\hline $\begin{array}{l}\text { Tingkat kepercayaan diri keluarga anggota KUBE Gakin dalam menjalin } \\
\text { hubungan di kelompoknya dengan peningkatan kesejahteraan ekonomi } \\
\text { keluarga }\end{array}$ & 0,321 \\
\hline $\begin{array}{l}\text { Tingkat kepercayaan antar keluarga anggota KUBE Gakin untuk bekerja } \\
\text { sama dengan peningkatan kesejahteraan ekonomi peningkatan } \\
\text { kesejahteraan ekonomi keluarga }\end{array}$ & $0,351 *$ \\
\hline $\begin{array}{l}\text { Tingkat kepercayaan antar keluarga anggota KUBE Gakin bahwa kerja sama } \\
\text { yang dilakukan dapat meningkatkan pendapatan dengan peningkatan } \\
\text { kesejahteraan ekonomi peningkatan kesejahteraan ekonomi keluarga }\end{array}$ & 0,314 \\
\hline $\begin{array}{l}\text { Tingkat kepercayaan antar keluarga anggota KUBE Gakin bahwa kerja sama } \\
\text { yang dilakukan dapat melancarkan usaha dengan peningkatan kesejahteraan } \\
\text { ekonomi keluarga }\end{array}$ & $0,388^{\star \pi}$ \\
\hline $\begin{array}{l}\text { Tingkat kepercayaan antar keluarga anggota KUBE Gakin bahwa aturan- } \\
\text { aturan di kelompok dapat menciptakan ketertiban jalannya kelompok dengan } \\
\text { peningkatan kesejahteraan ekonomi keluarga }\end{array}$ & 0,321 \\
\hline $\begin{array}{l}\text { Tingkat kepercayaan antar keluarga anggota KUBE Gakin untuk menjaga } \\
\text { keeratan hubungan dengan peningkatan kesejahteraan ekonomi keluarga }\end{array}$ & $0,367^{\pi m}$ \\
\hline $\begin{array}{l}\text { Tingkat kepercayaan antar keluarga anggota KUBE Gakin untuk menjamin } \\
\text { kelompok sustainable dengan peningkatan kesejahteraan ekonomi keluarga }\end{array}$ & $0,404^{\pi *}$ \\
\hline
\end{tabular}

Vol. 1 No. 1/Januari 2008 - 39 


\begin{tabular}{|c|c|}
\hline Hubungan antar variabel & $\begin{array}{l}\text { Koefisien } \\
\text { Spearman }\end{array}$ \\
\hline $\begin{array}{l}\text { Sifat jaringan keluarga dan anggota KUBE Gakin lain dengan peningkatan } \\
\text { kesejahteraan ekonomi keluarga }\end{array}$ & $-0,033$ \\
\hline $\begin{array}{l}\text { Sifat jaringan keluarga dan pengurus KUBE Gakin dengan peningkatan } \\
\text { kesejahteraan ekonomi keluarga }\end{array}$ & $-0,043$ \\
\hline $\begin{array}{l}\text { Luas jaringan usaha ekonomi keluarga dengan peningkatan kesejahteraan } \\
\text { ekonomi keluarga }\end{array}$ & $0,244^{*}$ \\
\hline $\begin{array}{l}\text { Kedalaman jaringan antara keluarga anggota KUBE Gakin dengan pengurus } \\
\text { dengan peningkatan kesejahteraan ekonomi keluarga }\end{array}$ & $0,203^{n}$ \\
\hline $\begin{array}{l}\text { Kedalaman jaringan antara keluarga anggota KUBE Gakin dengan anggota } \\
\text { lain yang sekelompok dengan peningkatan kesejahteraan ekonomi keluarga }\end{array}$ & 0,168 \\
\hline $\begin{array}{l}\text { Kedalaman jaringan antara keluarga anggota KUBE Gakin dengan anggota } \\
\text { lain yang berbeda kelompok dengan peningkatan kesejahteraan ekonomi } \\
\text { keluarga }\end{array}$ & 0,055 \\
\hline $\begin{array}{l}\text { Kedalaman jaringan antara keluarga anggota KUBE Gakin dengan } \\
\text { komunitasnya dengan peningkatan kesejahteraan ekonomi keluarga }\end{array}$ & 0,203 \\
\hline Keterbukaan jaringan dengan peningkatan kesejahteraan ekonomi keluarga & 0,021 \\
\hline Permanency jaringan dengan peningkatan kesejahteraan ekonomi keluarga & 0,019 \\
\hline $\begin{array}{l}\text { Keberadaan norma tertulis di dalam kelompok dengan peningkatan } \\
\text { kesejahteraan ekonomi keluarga }\end{array}$ & 0,378 \\
\hline $\begin{array}{l}\text { Keberadaan norma tidak tertulis di dalam kelompok dengan peningkatan } \\
\text { kesejahteraan ekonomi keluarga }\end{array}$ & \multirow{3}{*}{$\begin{array}{c}\text { Tidak ada } \\
\text { hubungan, } \\
\text { karena tidak } \\
\text { ada norma } \\
\text { tidak tertulis } \\
\text { yang diyakin } \\
\text { ada }\end{array}$} \\
\hline $\begin{array}{l}\text { Keberadaan norma tradisional di dalam kelompok dengan peningkatan } \\
\text { kesejahteraan ekonomi keluarga }\end{array}$ & \\
\hline $\begin{array}{l}\text { Keberadaan norma keagamaan di dalam kelompok dengan peningkatan } \\
\text { kesejahteraan ekonomi keluarga }\end{array}$ & \\
\hline
\end{tabular}

Sumber : $\quad$ Data primer diolah (2006)

Sementara itu, pada $\alpha=0,05$ juga diperoleh hubungan yang signifikan bahwa semakin luas jaringan (0.244) dan semakin dalam jaringan anggota KUBE Gakin dengan pengurus dan komunitas di sekitar lingkungan tempat tinggalnya (0.203) maka semakin tinggi perubahan kesejahteraan ekonomi keluarga. Hal ini menunjukkan bahwa apabila jaringan yang dimiliki anggota diperluas, dan juga bukan hanya sekedar mempunyai jaringan, tapi berinteraksi lebih mendalam khususnya dengan pengurus dan komunitasnya maka kemungkinan besar akan mampu meningkatkan kesejahteraan ekonomi anggota KUBE Gakin.

Begitupun dengan pilar norma, meskipun dalam kelompok tersebut hanya norma tertulis yang diyakini keberadaannya, namun keberadaan norma tertulis di dalam kelompok menunjukkan hubungan yang signifikan pada $\alpha=0.01$ terhadap peningkatan kesejahteraan ekonomi keluarga anggota UEK-SP Kube Gakin (0.378).

Uji korelasi antara norma sosial dengan perubahan ekonomi anggota KUBE Gakin menunjukkan bahwa keberadaan norma tertulis di dalam kelompok akan cenderung meningkatkan kesejahteraan ekonomi anggotanya. Sehingga peningkatan pengetahuan dan kesadaran anggota kelompok terhadap norma-norma yang ada sehingga terinternalisasi dengan baik pada diri anggota senantiasa dibutuhkan untuk dapat meningkatkan kapasitas anggota kelompok dalam meningkatkan kesejahteraan ekonomi keluarganya.

Keberadaan komponen modal sosial yang meliputi kepercayaan, jaringan sosial dan norma sosial tentu saja tidak dapat berdiri sendiri. Hasil penelitian, secara umum menunjukkan bahwa terdapat 
keterkaitan erat antara modal sosial dengan peningkatan kesejahteraan ekonomi keluarga miskin dalam kerangka pemberdayaan ekonomi komunitas. Hal ini menunjukkan bahwa keberadaan modal non materi, dalam hal ini berbentuk modal sosial, mempunyai peran yang cukup penting dalam mensukseskan program-program pemberdayaan ekonomi keluarga miskin.

\section{SIMPULAN DAN SARAN}

Simpulan

Secara umum, komponen modal sosial berupa kepercayaan, jaringan sosial, dan norma sosial yang dimiliki anggota kelompok dalam menjalin hubungan sosialnya berada dalam kategori sedang. Artinya, perlu ada upaya dari pihak-pihak terkait baik itu anggota, pengurus, maupun Dinas Tenaga Kerja dan Sosial Kota Bogor sebagai policy maker untuk saling bekerjasama mengoptimalkan potensi modal sosial yang timbul dari hubungan-hubungan sosial yang terjalin.

Keberadaan modal sosial mempunyai hubungan yang signifikan dengan peningkatan kesejahteraan ekonomi keluarga miskin anggota kelompok UEK-SP KUBE Gakin. Variabel modal sosial yang mempunyai hubungan signifikan pada $\alpha=0,01$ adalah kepercayaan dan norma tertulis yang ada di kelompok. Norma tidak tertulis, norma tradisional, dan norma agama tidak mempunyai hubungan dengan peningkatan kesejahteraan ekonomi keluarga miskin anggota kelompok UEK-SP KUBE Gakin karena ketiga jenis norma tersebut tidak ada di dalam kelompok.

Sementara itu, variabel jaringan sosial yang mempunyai hubungan signifikan dengan peningkatan kesejahteraan ekonomi anggota kelompok UEK-SP KUBE Gakin pada $\alpha=0,05$ adalah luas jaringan yang dimiliki anggota kelompok, kedalaman jaringan yang dimiliki anggota kelompok dalam berinteraksi dengan pengurus dan komunitasnya. Sementara itu, sifat jaringan (fungsional, struktural, dan transaksional), bentuk jaringan (formal dan informal), kedalaman jaringan dengan sesama anggota dan pihak lain tidak terdapat hubungan yang signifikan.

\section{Saran}

Berdasarkan kesimpulan dari penelitian ini maka saran yang ingin disampaikan oleh penulis terkait dengan peningkatan kesejahteraan ekonomi keluarga miskin melalui pemberdayaan ekonomi kelompok (komunitas) :

1. Kelompok usaha yang menghendaki perkembangan ekonomi lebih baik, perlu memupuk tumbuh dan berkembangnya modal sosial selain tersedianya jenis modal yang lain (modal finansial, modal fisik, modal alam, dan modal manuasia).

2. Strategi yang menyandarkan pada kekuatan modal sosial dalam pengembangan ekonomi rakyat melalui kelompok usaha berbasis komunitas memerlukan keterlibatan banyak pihak baik pemerintah, swasta, LSM-LSM serta para tenaga pendamping. Hal ini perlu disadari bahwa pelaku ekonomi rakyat adalah masyarakat yang notabene memiliki tingkat pengetahuan dan kualitas hidup yang rendah. Sehingga kadangkala mereka tidak menyadari bahwa hubungan-hubungan sosial yang mereka bangun dengan melandaskan pada kepercayaan, jaringan dan norma sosial yang dimiliki merupakan modal besar untuk membangun kondisi internal kelompok usaha berbasis komunitas yang tangguh. Sehingga perlu kiranya pengembangan-pengembangan kelompok usaha berbasis 
komunitas yang dilakukan menyertakan strategi-strategi yang menyandarkan pada kekuatan modal sosial seperti yang telah dirumuskan pada poin sebelumnya.

\section{Ucapan Terima Kasih:}

Penulis mengucapkan terima kasih kepada Lembaga Penelitian dan Pemberdayaan Masyarakat IPB. Penelitian yang disajikan dalam tulisan ini dapat terlaksana dengan Dana Hibah Penelitian Dosen Muda Tahun 2006 LPPM IPB.

\section{DAFTAR PUSTAKA}

[BPS] Badan Pusat Statistik Jawa Barat. 2003. Potret Sosial Ekonomi Masyarakat Jawa Barat Tahun 2003 (Hasil Susenas, 2003). Bandung: Badan Pusat Statistik.

[BPS] Badan Pusat Statistik Kota Bogor. 2006. Registrasi Keluarga Miskin Binaan Tahun 2006. Pemerintah Kota Bogor.

Christensen, J.A., Jerry, W.R.Jr. 1989. Community Development in Perspective. USA: lowa State University Press.

Dharmawan, A.H. 2002a. Kemiskinan Trust dan Stok Modal Sosial Masyarakat Indonesia Baru. Makalah disampaikan dalam Seminar dan Kongres Nasional IV Ikatan Sosiologi Indonesia. Bogor. 27-29 Agustus 2002.

Dharmawan AH. 2002b. Kemiskinan Kepercayaan (Trust), Stok Modal Sosial dan Disintegrasi Sosial. Perluasan dari makalah atas topik yang sama yang diajukan dalam
Seminar dan Kongres Nasional IV Ikatan Sosiologi Indonesia. Bogor. 27-29 Agustus 2002.

Fedderke, J., et al. 1999. Economic Growth and Social Capital : A critical Reflection. Netherlands: Kluwer Academic Publishers.

Fukuyama, F. 2001. Social Capital, Civil Society, and Development. Third Word Quarterly.

Gittell, R., Thompson, J.P. 2001. Making Social Capital Work: Social Capital and Community Economic Development. Di dalam : Saegert S, Thompson J, Warren MR, Editor. Social Capital and Poor Communities. New York: Russel Sage Foundation.

Grootaert, C. 1999. Social Capital, Household Welfare and Poverty in Indonesia. Social Development Department. The World Bank.

Skidmore, D. 2001. Civil Society, Social Capital and Economic Development. Global Society 15(1). Canterbury: University of Kent.

Stone, W., Hughes, J. 2002. Social Capital: Empirical Meaning and Measurement Validity. Research Paper No. 27, June 2002. Australian Institute of Family Studies.

Syahra, R., et.al. 2000. Anomie dan Modal Sosial : Memahami Krisis Multi Dimensional. Jakarta: Puslitbang Kemasyarakatan dan Kebudayaan LIPI.

Winter I. 2000. Towards a theorised understanding of family life and social capital. Working paper No. 21, April 2000. Australian Institute of Family Studies.

1 Staf Pengajar Departemen IImu Keluarga dan Konsumen, FEMA IPB 